\title{
EFFECT OF INTERCROPPING PATTERNS AND NITROGEN FERTILIZER LEVELS ON PRODUCTIVITY OF INTERCROPPED SUGAR BEET AND SUNFLOWER
}

\author{
Ahmed M. Sheha ${ }^{*}$, Amira A. El-Mehy and Y.A.A. Hefny \\ Crop Intensification Res. Dept. Agric. Res. Cent., Giza, Egypt
}

Received: 11/01/2017 ; Accepted: 21/01/2017

\begin{abstract}
Two field experiments were conducted during two winter successive seasons 2013/2014 and 2014/2015 at Gemmeza Research Station, El Gharbia Governorate, Egypt to study the effect of two patterns of mono cropping and intercropping i.e.: P1-Sunflower was planted in one row at the top of the terrace, $20 \mathrm{~cm}$ apart between hills one plant hill ${ }^{-1}\left(17500\right.$ plants fad. $\left.^{-1}\right)$ to achieve (100\% sugar beet $+50 \%$ sunflower). P2- Sunflower was planted in one row at top of the terrace, 30 $\mathrm{cm}$ apart between hills one plant hill ${ }^{-1}$ (11666 plants fad..$\left.^{-1}\right)$ to achieve $(100 \%$ sugar beet $+33.33 \%$ sunflower). P3- Sunflower was planted in one row at top of the terrace, $40 \mathrm{~cm}$ apart between hills one plant hill ${ }^{-1}$ ( 8315 plants fad. $^{-1}$ ) to achieve $(100 \%$ sugar beet $+25 \%$ sunflower). In all intercropping patterns, sugar beet was planted at $20 \mathrm{~cm}$ a part on two sides of the terrace $\left(35000\right.$ plants $\left.\mathrm{fad}^{-1}\right)$. The sole treatments of sugar beet and sunflower were grown at the recommended densities (35000 plants fad. $^{-1}$ ) $20 \mathrm{~cm}$, one plant hill ${ }^{-1}$ in one side in ridge $60 \mathrm{~cm}$ wide, and three nitrogen fertilizer levels (80, 100 and $120 \mathrm{~kg} \mathrm{~N}$ fad. $^{-1}$ ) on yield and land use efficiency of sugar beet (Beta vulgaris L.) - sunflower (Helianthus annuus (L.) Merr.) intercropped. The results showed that: root length and diameter, top and root weights plant ${ }^{-1}$ and top, root and sugar yields fad. ${ }^{-1}$, as well as purity, total soluble solids (\%) (TSS\%) and sucrose (\%) of sugar beet were significantly increased by reducing sunflower plant density in intercropped with sugar beet from 50 to 33.3 and up to $25 \%$ of its pure stand in both seasons and their combined analysis. The reduction in root yield fad. ${ }^{-1}$, of sugar beet were 8.64 and $4.58 \%$ for intercropping patterns which including 50.0 and $33.3 \%$ sunflower plant density of its pure stand in combined analysis, respectively, compared with $25.0 \%$. Increasing $\mathrm{N}$ fertilizer levels from 80 up to $120 \mathrm{Kg} \mathrm{N} \mathrm{fad}{ }^{-1}$, significantly increased all aforementioned traits of sugar beet, expect quality traits behaved with opposite trend in both seasons and combined analysis. There was significant effect of relay intercropping patterns in most sunflower traits. Plant height and seed yield fad. ${ }^{-1}$, of sunflower were significantly increased by increasing sunflower plant density with sugar beet from $25,33.3$ and up to $50 \%$, whereas yield components showed opposite trend in both seasons as well combined analysis. All aforementioned traits of sunflower were significantly increased by increasing $\mathrm{N}$ fertilizer level from 80,100 and up to $120 \mathrm{Kg} \mathrm{N} \mathrm{fad} .^{-1}$, in both seasons and combined analysis. The highest value of Land Equivalent Ratio (LER) 1.50, Land Equivalent Coefficient (LEC) (0.53), Area Time Equivalent Ratio (ATER) (1.15) were obtained with intercropping planting pattern (100\% sugar beet + $50 \%$ sunflower) at $120 \mathrm{Kg} \mathrm{N}_{\text {fad. }}{ }^{-1}$, and the best yield advantage Relative Crowding Coefficient (RCC) was obtained with $(100 \%$ sugar beet $+25 \%$ sunflower) at the same level of $\mathrm{N}$ fertilizer. The highest values of Monetary Advantage Index (MAI) (4750 LE) and gross profit (14252 LE) were showed with ( $100 \%$ sugar beet $+50 \%$ sunflower) under $120 \mathrm{Kg} \mathrm{N} \mathrm{fad}^{-1}$.
\end{abstract}

Key word: Sugar beet, sunflower, intercropping, nitrogen fertilizer, economic evaluation.

\footnotetext{
* Corresponding author: Tel. : +201001997720

E-mail address: dr.ahamedsheha67@yahoo.com
} 


\section{INTRODUCTION}

One of the main problems associated with the Egyptian agricultural system is the small area of cultivated land per farmer. In average, $42.9 \%$ of the farmers own or work in field area about one faddan $\left(4200 \mathrm{~m}^{2}\right.$ ) (Ahmed et al., 2009). This led to an increase need to maximize land usage to enhance farmer's income. The need to follow practices such as intercropping is a great importance in this context. Intercropping is growing two or more crops on the same spatial and temporal scales, for increasing productivity and profitability per unit area. Intercropping system is more productive than the sole (Umrani et al., 1984). The intercropping system greatly contributes to crop production by its effective utilization of resources compared to the monoculture cropping system (Zhang and Li, 2003). Currently, this system was interestingly increasing in low-input crop production systems and was being extensively investigated.

Sugar beet (Beta vulgaris L.) is an important crop, worldwide as source of sugar industry. In Egypt, it is the second sugar crop after sugar cane. Egyptian Government imports large amounts of sugar every year to contribute in reducing sugar deficiency gap. Increasing sugar yield per unit area had national interest and it can be achieved by adopting suitable cultural practices such as intercropping system. The area that allocated to sugar beet in Egypt had increased mostly in the recent years (16900 fad., at 1982 to 450000 fad., at 2012 season). Also, sugar beet production from sugar beet largely increased, since the cultivated area in Egypt is limited, the agriculture intensification had become urgent necessity to optimize the utilizing of unit area (Abdel Motagally and Metwally, 2014).

Sunflower (Helianthus annuus L. Merr.) is one of the most cultivated oil crops in the world. In recent years, the planted area has increased, sunflower high oil yield due to its ability to tolerate short periods of water deficit (Hattendorf et al., 1988). The oil seeds are the second food stocks after the cereals in the world. Because they not only have enriched of fatty acids but also they are full of proteins. Of these oil seeds, the sunflower is the fourth annual crop as food oil. Sunflower having features such as suitable climate adaptation, soil, high quality of the oil, short growth duration, suitable oil cake, is considered as the most favorable oil productions (Tavakoli, 2013).

Plant density and nitrogen fertilizer level were the most important agronomic practices affected on sunflower yield and seed oil percentage (Bader and Rashed, 1988). Seed yield was positively correlated with plant density, but plant height, head diameter, 100seed weight and seed yield plant ${ }^{-1}$ were decreased with increasing plant density (Allam and Galal, 1996).

Sugar beet-sunflower intercropping considerably increased monetary returns and produced positive impacts on the soil health and nutrition for the next crop (Stoyanov et al., 1997). The intercropping system like sugar beet with cereal crops or with oil seed crops could provide the farmer with high gross returns (Lal and Mukerji, 1998). Badraoui et al. (2003) cultivated wheatsugar beet or sunflower in the irrigated regions of Morocco and recommended sugar beet and sunflower as companion crops. El-Dessougi et al. (2003) reported that grown sugar beet with oil seed crops produced higher monetary returns than other companion crops. Tichy et al. (2001) found that sugar beet + sunflower increased sunflower yield more than 5 tons ha ${ }^{-1}$ and sugar beet/sunflower intercropping was appeared as most successful companion crops with net benefits.

Nitrogen is the most limiting essential nutrient for sunflower and sugar beet production. It is the main driving force to produce large yields because nitrogen is vitally important and is required in large amounts. Shalaby (1995) reported that $\mathrm{N}$ fertilizer increased plant height, head diameter, seed yield plant $^{-1}$, and seed yield $\mathrm{fad}^{-1}$ of sunflower. Abd El-Wahed (1996) found that $60 \mathrm{~kg} \mathrm{~N} \mathrm{fad} .^{-1}$, adding to sunflower, resulted in maximum plant height, head diameter, seed yield plant ${ }^{-1}$, weight of 100 seeds, seed yield fad $^{-1}$. The interaction between plant spacing and nitrogen rate significantly affected seed oil yield (Bader and Rashed, 1988).

Also, nitrogen is the most important fertilizer elements for sugar beet growth and yield (Badawi, 1989; El-Kassaby and Leilah, 1992). Increasing nitrogen rate up to $120 \mathrm{~kg} \mathrm{~N}$ fad. ${ }^{-1}$, 
significantly increased root length, root diameter as well as root, top and sugar yields fad. ${ }^{-1}$, of sugar beet, but it resulted in marked reduction in TSS, juice purity and sucrose (\%) (Sorour et al., 1992; El-Hannawy et al., 1998).

The present investigation was planned to study the effect of intercropping patterns of sunflower- sugar beet and different $\mathrm{N}$ fertilizer levels on yield and its components of sunflower and sugar beet as well as quality traits of sugar beet and competitive relationships and monetary advantages.

\section{MATERIALS AND METHODS}

Two field experiments were carried out in Gemmeza Research Station, El-Gharbia Governorate, during two winter successive growing seasons 2013/2014 and 2014/2015 to study the effect of two planting patterns (sole cropping and intercropping) i.e.: P1-Sunflower was planted in one row at the top of the terrace, $20 \mathrm{~cm}$ apart between hills one plant hill ${ }^{-1}(17500$ plants fad. $\left.{ }^{-1}\right)$ to achieve $(100 \%$ sugar beet $+50 \%$ sunflower). P2- Sunflower was planted in one row at top of the terrace, $30 \mathrm{~cm}$ apart between hills, one plant hill ${ }^{-1}$ (11666 plants fad. $\left.{ }^{-1}\right)$ to achieve (100\% sugar beet $+33.33 \%$ sunflower). P3-Sunflower was planted in one row at top of the terrace, $40 \mathrm{~cm}$ apart between hills one plant $\operatorname{hill}^{-1}\left(8315\right.$ plants fad. $\left.{ }^{-1}\right)$ to achieve $(100 \%$ sugar beet $+25 \%$ sunflower). In all intercropping patterns, sugar beet was planted at $20 \mathrm{~cm}$ a part on two sides of the ridge ( 35000 plants fad..$^{-1}$ ).

Sole treatments of sugar beet and sunflower were grown at the recommended densities $\left(35000\right.$ plants $^{-1}$ fad $\left.^{-1}\right) 20 \mathrm{~cm}$, one plant hill ${ }^{-1}$ in one side in ridge $60 \mathrm{~cm}$ wide and three nitrogen fertilizer levels $\left(80,100\right.$ and $120 \mathrm{~kg} \mathrm{~N} \mathrm{fad}^{-1}$.) on yield and yield components as well as yield advantages of sugar beet (Beta vulgaris L.) cv. Kawemira and sunflower (Helianthus annuus L. Merr.) cv. Giza 102 in intercropping patterns.

Before sowing, the land was prepared and leveled with rotary plough to a depth of $15 \mathrm{~cm}$. The soil was clay loam in texture had an average $\mathrm{pH}$ value of $8.1 ; 1.3 \%$ organic matter and had 37, 12 and $380 \mathrm{ppm}$ available $\mathrm{N}, \mathrm{P}$ and $\mathrm{K}$, respectively (averaged over the two seasons for the upper $30 \mathrm{~cm}$ of soil depth).
Seeds of sugar beet and sunflower were sown on $11^{\text {th }}$ and $15^{\text {th }}$ November and $1^{\text {st }}$ and $3^{\text {rd }}$ March and harvested on $5^{\text {th }}$ and $7^{\text {th }}$ June and $23^{\text {rd }}$ and $26^{\text {th }}$ May in both seasons, for two crops in sole planting and intercropping system, respectively. After three weeks from planted in solid as well as intercropping planting, the plants were thinned to one plant per hill after 21 days for both crops.

The treatments were arranged in split-plot design with three replicates.

Nine treatments were applied i.e. combination of three planting patterns $(25,33.33$ and $50 \%$ of sunflower pure stand) with sugar beet and three nitrogen fertilizer levels $(80,100$ and $120 \mathrm{~kg} \mathrm{~N}$ $\mathrm{fad}^{-1}$ ) in addition to pure stand of sunflower and sugar beet as recommended. Where, the planting patterns occupied the main plots in intercropped patterns. The nitrogen fertilizer levels were arranged in $1^{\text {st }}$ order sub-plots. The field treatment i.e., sub- plots included five terraces, $3.5 \mathrm{~m}$ long and $1.2 \mathrm{~m}$ width. Thus, the plot area was $21 \mathrm{~m}^{2}$.

The solid culture did not included in the statistical analysis, but planted in purpose of estimating the competitive relationship and economic return. The preceding summer crop was maize (Zea mays L.) in both seasons.

Nitrogen fertilizer was applied to sole and intercropped sugar beet and sunflower in the form of urea $(46 \% \mathrm{~N})$ in four doses, $20 \%$ at the first irrigation, $30 \%$ at the second irrigation, $30 \%$ at the third irrigation of sugar beet while the last dose $20 \%$ was added after thinning sunflower. A basal dose of $\mathrm{P}$ and $\mathrm{K}$ corresponding to $30 \mathrm{~kg} \mathrm{P}_{2} \mathrm{O}_{5}$ as super phosphate fertilizer $\left(15.5 \% \quad \mathrm{P}_{2} \mathrm{O}_{5}\right)$ and $24 \mathrm{~kg} \mathrm{~K}_{2} \mathrm{O}$ as potassium sulfate $\left(50 \% \quad \mathrm{~K}_{2} \mathrm{O}\right)$ fertilizer was uniformly broadcasted at the time of seedbed preparation. All the other practices were applied as recommended for each crop. The other agricultural practices were applied as recommended.

\section{Data Recorded}

\section{Sugar beet}

Ten guarded plants were randomly taken at harvest from the central ridge of each sub- plot to estimate: root length $(\mathrm{cm})$, root diameter $(\mathrm{cm})$, top and root fresh weight plant $^{-1}(\mathrm{~kg})$, top 
and root yields were determined on the whole plot basis then it were transferred to tons fad ${ }^{-1}$.

\section{Juice quality characteristics}

Samples of fresh root were taken from each sub plot to determine:

1. Total soluble solids (\%) (TSS \%) measured by refract meter according to AOAC (1990).

2. Sucrose percentage was determined according to method describing by Le-Docte (1927).

3. Juice purity percentage was calculated according to the method describing by Carruthers and Old Field (1961).

Purity $(\%)=\frac{\text { Sucrose }}{\text { TSS }(\%)} \times 100$

4. Gross sugar yield (ton fad. $\left.{ }^{-1}\right)=$ root yield (ton fad. $\left.^{-1}\right) \times($ sugar $\%)$

\section{Sunflower}

Ten sunflower guarded plants were randomly taken at harvest from each sub-plot to estimate: plant height $(\mathrm{cm})$, head diameter $(\mathrm{cm}), 100$-seed weight $(\mathrm{g})$ and seed yield plant ${ }^{-1}(\mathrm{~g})$. Sunflower plants were harvest and threshed from each subplots to estimate the seed yield $\left(\mathrm{kg} \mathrm{fad} .^{-1}\right)$.

\section{Competitive Relationships and Economic Evaluations}

\section{Land use efficiency}

In order to assess the land use efficiency, total land equivalent ratio (LER), land equivalent coefficient (LEC), area time equivalent ratio (ATER), relative crowding coefficient (RCC) and aggressivity were determined for each yield recorded per faddan i.e. root + seed. This was achieved for cropping systems.

\section{Total Land equivalent ratio (Total LER)}

Was suggested by (Monzon et al., 2014). It was determined according to do as the sums of yield relative i.e. intercrop yields relative to their solid yield. The total LER an accurate assessment of the biological efficiency of the intercropping situation, using the following equation to evaluate and compare the productivity of intercropping and mono cropping: Total LER $=(\mathrm{Yab} / \mathrm{Yaa})+(\mathrm{Yba} / \mathrm{Ybb})$.
Where, Yaa and $\mathrm{Ybb}$ are yields as sole crops of $\mathrm{a}$ (sugar beet) and $\mathrm{b}$ (sunflower) and $\mathrm{Yab}$ and Yba are yields as intercrops of $a$ and $b$, respectively. Values of total LER greater than 1.0 are considered advantages. While, values of total LER less than 1.0 are considered disadvantages.

\section{Land equivalent coefficient (LEC)}

A measure of interaction concerned with the strength of relationship was calculated thus, $\mathrm{LEC}=\mathrm{La} \times \mathrm{Lb}$. Where, $\mathrm{La}=$ partial LER of main crop and $\mathrm{Lb}=$ partial LER of intercrop (Aditiloye et al., 1983). For a two- crop mixture the minimum expected productivity coefficient (PC) is $25 \%$ that is a yield advantage is obtained if LEC exceeds 0.25 .

\section{Area time equivalent ratio (ATER)}

The ratio of number of hectare-days required in monoculture to the number of hectare-days used in the intercrop to produce identical quantities of each of the components, was calculated according to Hiebsch and McCollum (1987) as follows:

$$
\begin{aligned}
& \text { ATER }=(\mathrm{RYa} \times \mathrm{ta})+(\mathrm{RY} b \times \mathrm{tb}) / \mathrm{T} \text { or } \mathrm{ATER}= \\
& \left(\frac{\mathrm{Yab}}{\mathrm{Yaa}} \times \mathrm{ta}\right)+\left(\frac{\mathrm{Yba}}{\mathrm{Ybb}} \times \mathrm{tb}\right) / \mathrm{T} .
\end{aligned}
$$

Where:

RY=Relative yield of crop (a) sugar beet or crop (b) sunflower i.e., yield of intercrop/yield of main crop, $t=$ duration (days) for species $a$ or $b$ and $\mathrm{T}=$ duration (days) of the intercropping system.

\section{Relative crowding coefficient (RCC)}

RCC was proposed according to De-Wit (1960). It assumes that mixture treatment forms a replacement crops. Each crop has its own coefficient $(\mathrm{K})$ which gives a measure to indicate that crop has produced more, less or equal yield to that expected. It was calculated as follows:

$$
\mathrm{K}=\mathrm{K}_{\mathrm{a}} \times \mathrm{K}_{\mathrm{b}}
$$

Where:

$\mathrm{Ka}$ for sugar beet, $\mathrm{Kb}$ for sunflower and $\mathrm{K}$ for the two crops were calculated as follows: 
$\left.\mathrm{K}_{\mathrm{a}}=\mathrm{Y}_{\mathrm{ab}} \times \mathrm{Z}_{\mathrm{ba}} /\left[\left(\mathrm{Y}_{\mathrm{aa}}-\mathrm{Y}_{\mathrm{ab}}\right) \times \mathrm{Z}_{\mathrm{ab}}\right)\right], \mathrm{K}_{\mathrm{b}}=\mathrm{Y}_{\mathrm{ba}} \mathrm{x}$ $\left.\mathrm{Z}_{\mathrm{ab}} /\left[\left(\mathrm{Y}_{\mathrm{bb}}-\mathrm{Y}_{\mathrm{ba}}\right) \times \mathrm{Z}_{\mathrm{ba}}\right)\right]$

Where:

$\mathrm{Zab}=$ sown proportion of crop a (sugar beet) in $\mathrm{a}$ intercropping with $\mathrm{b}$. $\mathrm{Zba}=$ sown proportion of crop b (sunflower) in b intercropping with $a$.

If a crop has a coefficient less than, equal to or greater than 1 , it means it has produced less yield, the same yield or more yield than the expected, respectively.

\section{Aggressivity (A)}

Is another index represents a simple measure of how much the relative yield increase in crop a is greater than that of crop b in an intercropping system. It was calculated as: $\mathrm{Aab}=(\mathrm{Yab} / \mathrm{Yaa}$ $\mathrm{xZab})-(\mathrm{Yba} / \mathrm{Ybb} \times \mathrm{Zba})$. Where, Yaa and $\mathrm{Ybb}$ are yields as sole crops of $a$ and $b$ and $Y a b$ and $\mathrm{Yba}$ are yields as intercrops of $\mathrm{a}$ and $\mathrm{b}$. Zab and $\mathrm{Zba}$ are the sown proportions of $\mathrm{a}$ and $\mathrm{b}$, respectively. If $A a b=0$, both crops are equally competitive, if $\mathrm{Aab}$ is positive, $\mathrm{A}$ is dominant, if Aab is negative a is dominated crop (Ghosh et al., 2006).

\section{Economic evaluations}

\section{Monetary advantage index (MAI)}

The price of sugar beet and sunflower were 370,54 and $3605 \mathrm{LE}$ in $1^{\text {st }}$ season and 379,57 and $3764 \mathrm{LE}$ in $2^{\text {nd }}$ season for root, top and seed yield per ton, respectively (Bulletin of Statistical Cost Production and Net Return, 2013/2014 and 2014/2015). It suggests that the economic assessment should be in terms of the value of land saved; this could probably be most assessed on the basis of the rentable value of this land. Monetary advantage index (MAI) was calculated according to the formula, suggested by Willey (1979).

MAI $=[$ Value of combined intercrops $\times($ LER 1)]/LER

Gross profit from each treatment was calculated in Egyptian pounds (LE) using the average market price of two seasons (Bulletin of Statistical Cost Production and Net Return, 2013/2014 and 2014/2015).

\section{Statistical Analysis}

The obtained data were statistically analyzed according to Steel et al. (1997), using "MSTAT-
C" computer software package. Least significant differences was used for the comparison between means. Means having the same letters are not significantly different. A combined analysis was made for the data of the two seasons by using the Bartlett's test statistic for homogeneity of variance. In interaction tables capital and small letters were used for comparisons among means of rows and columns, respectively.

\section{RESULTS AND DISCUSSION}

\section{Sugar Beet}

\section{Relay intercropping planting patterns effect}

Results in Table 1 reveal that root length $(\mathrm{cm})$, root diameter $(\mathrm{cm})$, root weight plant ${ }^{-1}$ (kg), top fresh weight Plant $^{-1}(\mathrm{~kg})$, top fresh yield fad. ${ }^{-1}$ (ton) and root yield fad. ${ }^{-1}$ (ton) of sugar beet were significantly affected by intercropping patterns in both seasons as well as in combined analysis except, root weight plant ${ }^{-1}$, where the differences among intercropping patterns did not reach the level of significant. Root length was significantly increased by decreasing sunflower plant density from 50 to 33.3 to $25 \%$ of its pure stand in both seasons. The highest values of aforementioned traits were recorded with $\mathrm{P}_{3}(100 \%$ sugar beet $+25 \%$ sunflower) followed by $\mathrm{P}_{2}(100 \%+33.3 \%)$ and the lowest value was showed with $\mathrm{P}_{1}(100 \%$ sugar beet $+50 \%$ sunflower) in both seasons and combined analysis. This results may be due to intra and inter-specific competition between sugar beet plants and sugar beet with sunflower plants for light, water and nutrients. Similar results were obtained by Sorour et al. (1992), El-Hannawy et al. (1998), Osman and Awed (2010) and Mohammed and Abd El-Zaher (2013).

Intercropping pattern $\mathrm{P}_{3}(100 \%$ sugar beet+ $25 \%$ sunflower) surpassed in root yield $\mathrm{fad}^{-1}$ compared with $\mathrm{P}_{1}$ and $\mathrm{P}_{2}$ by 9.47 and $4.77 \%$, respectively in their combined analysis. These results were in agreement with those obtained by Salama and Badawi (1996), Fahmi (1999) and Zhang and Li (2003).

Juice quality characteristics of sugar beet i.e. TSS (\%), sucrose $(\%)$, purity $(\%)$ and gross sugar yield fad. ${ }^{-1}$, were significantly decreased by increasing sunflower plant density from 25.0 
Table 1. Root length $(\mathrm{cm})$, root diameter $(\mathrm{cm})$, root weight plant ${ }^{-1}(\mathrm{~kg})$, top fresh weight plant $^{-1}(\mathrm{~kg})$, top fresh yield fad. ${ }^{-1}$ (ton) and root yield fad. ${ }^{-1}$ (ton) of sugar beet as affected by intercropping patterns and $\mathrm{N}$ fertilizer levels in both seasons and their combined analysis

\begin{tabular}{|c|c|c|c|c|c|c|c|c|c|}
\hline \multirow[t]{2}{*}{ Main effects and interaction } & \multicolumn{3}{|c|}{ Root length (cm) } & \multicolumn{3}{|c|}{ Roots diameter (cm) } & \multicolumn{3}{|c|}{ Root weight plant $^{-1}(\mathrm{~kg})$} \\
\hline & $2013 / 2014$ & $2014 / 2015$ & Comb. & $2013 / 2014$ & $2014 / 2015$ & Comb. & $2013 / 2014$ & $2014 / 2015$ & Comb. \\
\hline \multicolumn{10}{|l|}{ intercropping pattern (P) } \\
\hline$P_{1}(100 \%$ sugar beet $+50.00 \%$ sunflower $)$ & $24.17 b$ & $26.00 \mathrm{~b}$ & $25.08 \mathrm{c}$ & $10.86 \mathrm{c}$ & $12.09 \mathrm{c}$ & $11.47 \mathrm{c}$ & 0.660 & 0.700 & 0.680 \\
\hline$P_{2}(100 \%$ sugar beet $+33.33 \%$ sunflower $)$ & $26.42 \mathrm{a}$ & $27.33 b$ & $26.88 b$ & $12.61 \mathrm{~b}$ & $13.44 \mathrm{~b}$ & $13.03 \mathrm{~b}$ & 0.620 & 0.810 & 0.720 \\
\hline$P_{3}(100 \%$ sugar beet $+25.00 \%$ sunflower $)$ & $27.98 \mathrm{a}$ & $31.56 \mathrm{a}$ & $29.77 \mathrm{a}$ & $14.19 \mathrm{a}$ & $16.11 \mathrm{a}$ & $15.15 \mathrm{a}$ & 0.710 & 0.770 & 0.740 \\
\hline F test & $*$ & $*$ & $*$ & $*$ & $*$ & $*$ & NS & NS & NS \\
\hline \multicolumn{10}{|l|}{$\mathbf{N}$ fertilizer level $\left(\mathrm{kg} \mathrm{fad}^{-1}\right) \quad(\mathrm{N})$} \\
\hline $\mathbf{N}_{2} 100$ & $25.43 b$ & $28.33 \mathrm{ab}$ & $26.88 \mathrm{~b}$ & $12.22 \mathrm{~b}$ & $13.78 \mathrm{ab}$ & $13.00 \mathrm{~b}$ & $0.780 \mathrm{a}$ & $0.740 \mathrm{~b}$ & $0.760 \mathrm{a}$ \\
\hline $\mathbf{N}_{3} \mathbf{1 2 0}$ & $28.48 \mathrm{a}$ & $29.89 \mathrm{a}$ & $29.18 \mathrm{a}$ & $13.53 \mathrm{a}$ & $14.89 \mathrm{a}$ & $14.21 \mathrm{a}$ & $0.760 \mathrm{a}$ & $0.880 \mathrm{a}$ & $0.820 \mathrm{a}$ \\
\hline F. test & $*$ & $*$ & $*$ & $*$ & $*$ & $*$ & $*$ & $*$ & $*$ \\
\hline Interaction $\mathbf{P} \times \mathbf{N}$ & NS & NS & NS & NS & NS & NS & NS & NS & NS \\
\hline Solid & 29.27 & 32.47 & 30.87 & 17.33 & 16.29 & 16.81 & 0.79 & 0.82 & 0.81 \\
\hline \multirow[t]{2}{*}{ Main effects and interaction } & \multicolumn{3}{|c|}{ Top fresh weight plant ${ }^{-1}(\mathrm{~kg})$} & \multicolumn{3}{|c|}{ Top fresh yield fad. ${ }^{-1}$ (ton) } & \multicolumn{3}{|c|}{ Root yield fad. $^{-1}$ (ton) } \\
\hline & 2013/20142 & $2014 / 2015$ & Comb. & 2013/2014 & $2014 / 2015$ & Comb. & 2013/2014 & $2014 / 2015$ & Comb. \\
\hline$P_{2}(100 \%$ sugar beet $+33.33 \%$ sunflower $)$ & $0.550 \mathrm{~b}$ & $0.610 \mathrm{a}$ & $0.580 \mathrm{~b}$ & $13.82 b$ & $16.19 b$ & $15.00 \mathrm{~b}$ & $28.72 \mathrm{ab}$ & $29.09 \mathrm{ab}$ & $28.91 b$ \\
\hline$P_{3}(100 \%$ sugar beet $+25.00 \%$ sunflower $)$ & $0.600 \mathrm{a}$ & $0.660 \mathrm{a}$ & $0.630 \mathrm{a}$ & $15.35 \mathrm{a}$ & $17.34 \mathrm{a}$ & $16.34 \mathrm{a}$ & $30.87 \mathrm{a}$ & $29.72 \mathrm{a}$ & $30.29 a$ \\
\hline F. test & $*$ & $*$ & $*$ & $*$ & $*$ & $*$ & $*$ & $*$ & $*$ \\
\hline \multicolumn{10}{|l|}{$\mathbf{N}$ fertilizer level $\left(\mathrm{kg} \mathrm{fad}^{-1}\right) \quad(\mathrm{N})$} \\
\hline $\mathbf{N}_{1} 80$ & $0.460 \mathrm{c}$ & 0.570 & $0.520 \mathrm{c}$ & $12.00 \mathrm{c}$ & $13.86 \mathrm{c}$ & $12.93 \mathrm{c}$ & $26.50 b$ & $26.42 \mathrm{c}$ & $26.46 \mathrm{c}$ \\
\hline $\mathbf{N}_{2} 100$ & $0.540 \mathrm{~b}$ & 0.600 & $0.570 \mathrm{~b}$ & $13.73 b$ & $15.68 b$ & $14.70 b$ & $29.46 \mathrm{a}$ & $29.20 b$ & $29.33 b$ \\
\hline$N_{3} 120$ & $0.610 \mathrm{a}$ & 0.640 & $0.620 \mathrm{a}$ & $15.59 \mathrm{a}$ & $17.85 \mathrm{a}$ & $16.72 \mathrm{a}$ & $30.96 a$ & $31.21 \mathrm{a}$ & $31.08 \mathrm{a}$ \\
\hline F. test & $*$ & NS & $*$ & $*$ & $*$ & $*$ & $*$ & $*$ & $*$ \\
\hline Interaction $\mathbf{P} \times \mathbf{N}$ & NS & NS & NS & NS & NS & NS & NS & NS & NS \\
\hline Solid & 0.54 & 0.68 & 0.61 & 11.65 & 13.90 & 12.78 & 32.21 & 32.89 & 32.55 \\
\hline
\end{tabular}

NS and * meaning; Not significant and significant at 0.05 level, respectively. 
to 33.3 up to $50.0 \%$ of its pure stand of sunflower in both seasons and combined analysis as shown in Table 2. The highest values of above traits were obtained from relay intercropping planting pattern $\mathrm{P}_{3}(100 \%+25 \%)$ followed by $\mathrm{P}_{2}(100 \%+33.3)$, while the lowest value was showed with $\mathrm{P}_{1}(100 \%+50 \%)$ sugar beet/ sunflower in both seasons and combined analysis. This reduction may be due to intra and inter competition between sugar beet and sunflower. Shading effect of sunflower plants on sugar beet plants reduces the process of photosynthesis, formation of sugar in the leaves and its transmission to roots. Similar results were obtained by Salama and Badawi (1996), Fahmi (1999), Mohammed and Abd El-Zaher (2013) and Zhang and Li (2003)

\section{$\mathbf{N}$ fertilizer level effect}

Results in Tables 1 and 2 reveal that all studied characters of sugar beet were significantly affected by $\mathrm{N}$ fertilizer level in both seasons and combined analysis except TSS\% where the level of significant did not reach the level of significant during $2^{\text {nd }}$ season and the combined.

The results in Tables 1 and 2 show that root length of sugar beet was significantly increased by increasing nitrogen level from 80 , to $120 \mathrm{Kg}$ $\mathrm{N} /$ fad., in both seasons and combined analysis. The increase reached about 4.75 and $13.71 \%$, 4.50 and $14.22 \%, 38.18$ and $49.09 \%, 9.61$ and $19.23 \%, 13.68$ and $29.31 \%$ as well as 10.84 and $17.46 \%$ for root length, root diameter, root weight plant $^{-1}$, top fresh weight plant ${ }^{-1}$, top fresh yield $\mathrm{fad}^{-1}$ and root yield (ton) $\mathrm{fad}^{-1}$ due to application the $1^{\text {st }}$ and $2^{\text {nd }} \mathrm{N}$ increment during the combined analysis, respectively. These results may be due to the role of $\mathrm{N}$ in activation the growth by stimulation effect for cell elongation, directly after division where nitrogen plans an important role in root length of sugar beet as well as for root diameter. The results coincided with Badawi (1989), Sorour et al. (1992), Shalaby (1995), Salama and Badawi (1996), El-Hannawy et al., (1998), Fahmi (1999) and Neana (1999).

Concerning juice quality traits i.e., TSS (\%), sucrose (\%) and purity (\%) and gross sugar yield (ton $\mathrm{fad}^{-1}$ ) were significantly increased by increasing $\mathrm{N}$ fertilizer level from 80 to $100 \mathrm{Kg}$
$\mathrm{N}$ fad $^{-1}$ in both seasons and combined analysis as shown in Table 2. The gross sugar yield is an important yield parameter. The differences in root yield and sugar (\%) between traits reflected the differences in sugar yield ton fad. ${ }^{-1}$. The highest gross sugar yield (4.21 ton fad. ${ }^{-1}$ ) was achieved at $100 \mathrm{Kg} \mathrm{N}$ fad. $^{-1}$ and followed by 120 $\mathrm{Kg} \mathrm{N}$ fad. ${ }^{-1}$ (3.94 ton fad. ${ }^{-1}$ ) in the combined analysis. Similar results were obtained with Sorour et al. (1992) and El-Hannawy et al. (1998).

\section{Interaction effect}

The interaction effect between relay intercropping planting patterns sugar beetsunflower and $\mathrm{N}$ fertilizer levels had no significantly effect on yield characteristics of sugar beet in both seasons and combined analysis as shown in Tables 1 and 2. While all juice quality traits of sugar beet were significantly affected except $\mathrm{TSS} \%$ in the second season and combined analysis. This means that each of these factors act independently on their effect in these characteristics, consequently the results were excluded.

\section{Sunflower}

\section{Intercropping planting patterns effect}

Results in Table 3 reveal that plant height, head diameter, seed yield plant $^{-1}, 100$ seed weight and seed yield fad ${ }^{-1}$ were significantly affected by intercropping patterns in both seasons as well as combined analysis.

Results presented in Table 3 show marked and significant increase in plant height by increasing sunflower plant density from 25 to 33.3 to $50 \%$ of its pure stand $\left(35,000\right.$ plants fad. $\left.{ }^{-1}\right)$ when intercropped with sugar beet. This increase in sunflower plant height is mainly due to the increase in intra-specific competition on solar radiation at higher sunflower density and vice versa. Similar Results were obtained by Osman and Awed (2010) and Mohammed and Abd El-Zaher (2013). In contrary, traits i.e. head diameter, 100 seed weight and seed yield plant ${ }^{-1}$ behaved the opposite trend of plant height in both seasons as well as combined analysis. The reduction in these traits were 24.8 and $8.3 \%$, 14.4 and 8.4 and 23.7 and $9.4 \%$ for head diameter, 100 seed weight and seed yield plant ${ }^{-1}$, respectively, when intercropped sunflower with 
Table 2. TSS\%, Sucrose (\%), purity (\%) and Gross sugar yield (ton fad. ${ }^{-1}$ ) of sugar beet as affected by intercropping patterns and $\mathrm{N}$ fertilizer levels and interaction in both seasons and their combined analysis

\begin{tabular}{|c|c|c|c|c|c|c|c|c|c|c|c|c|c|}
\hline \multirow{2}{*}{\multicolumn{2}{|c|}{ Main effects and interaction }} & \multicolumn{3}{|c|}{ TSS (\%) } & \multicolumn{3}{|c|}{ Sucrose $(\%)$} & \multicolumn{3}{|c|}{ Purity (\%) } & \multicolumn{3}{|c|}{ Gross sugar yield (ton fad..$^{-1}$ ) } \\
\hline & & \multirow[t]{2}{*}{ 2013/14 } & \multicolumn{2}{|c|}{ 2014/15 Comb. } & \multirow[t]{2}{*}{ 2013/14 } & \multirow[t]{2}{*}{ 2014/15 } & \multirow[t]{2}{*}{ Comb. } & \multirow[t]{2}{*}{ 2013/14 } & \multirow[t]{2}{*}{ 2014/15 } & \multirow[t]{2}{*}{ Comb. } & \multirow[t]{2}{*}{ 2013/14 } & \multirow[t]{2}{*}{$2014 / 15$} & \multirow[t]{2}{*}{ Comb. } \\
\hline \multicolumn{4}{|l|}{ Intercropping pattern (P) } & & & & & & & & & & \\
\hline \multicolumn{2}{|c|}{$P_{1}(100 \%$ sugar beet $+50.00 \%$ sunflower $)$} & $17.07 \mathrm{c}$ & 16.64 & 16.85 & $12.99 \mathrm{~b}$ & $13.13 b$ & $13.06 \mathrm{~b}$ & $76.10 \mathrm{c}$ & $78.91 b$ & $77.50 \mathrm{c}$ & $3.55 b$ & $3.67 \mathrm{c}$ & $3.61 b$ \\
\hline \multicolumn{2}{|c|}{$P_{2}(100 \%$ sugar beet $+33.33 \%$ sunflower $)$} & $17.76 \mathrm{~b}$ & 16.81 & 17.28 & $13.64 \mathrm{ab}$ & $13.35 \mathrm{a}$ & $13.49 \mathrm{ab}$ & $76.80 \mathrm{~b}$ & $79.42 \mathrm{a}$ & $78.11 b$ & $3.89 b$ & $3.88 \mathrm{~b}$ & $3.89 \mathrm{ab}$ \\
\hline \multicolumn{2}{|c|}{$P_{3}(100 \%$ sugar beet $+25.00 \%$ sunflower $)$} & $18.11 \mathrm{a}$ & 17.11 & 17.60 & $14.59 \mathrm{a}$ & $13.48 \mathrm{a}$ & $14.03 \mathrm{a}$ & $80.56 \mathrm{a}$ & $78.78 \mathrm{ab}$ & $79.67 \mathrm{a}$ & $4.50 \mathrm{a}$ & $4.00 \mathrm{a}$ & $4.25 \mathrm{a}$ \\
\hline \multicolumn{2}{|c|}{ F. test } & * & NS & NS & $*$ & $*$ & $*$ & $*$ & * & * & * & $*$ & $*$ \\
\hline \multicolumn{2}{|l|}{$\mathbf{N}_{1} 80$} & $17.63 b$ & $17.18 \mathrm{a}$ & $17.40 \mathrm{a}$ & $13.78 \mathrm{a}$ & $13.46 \mathrm{~b}$ & $13.62 \mathrm{a}$ & $78.16 b$ & $78.35 \mathrm{c}$ & $78.25 b$ & $3.65 \mathrm{c}$ & $3.56 b$ & $3.61 b$ \\
\hline \multicolumn{2}{|l|}{$\mathbf{N}_{2} \mathbf{1 0 0}$} & $18.50 \mathrm{a}$ & $17.56 \mathrm{a}$ & $18.03 \mathrm{a}$ & $14.75 \mathrm{a}$ & $13.87 \mathrm{a}$ & $14.31 \mathrm{a}$ & $79.73 a$ & $78.99 b$ & $79.36 \mathrm{a}$ & $4.37 \mathrm{a}$ & $4.05 \mathrm{a}$ & $4.21 \mathrm{a}$ \\
\hline \multicolumn{2}{|l|}{$N_{3} 120$} & $16.81 \mathrm{c}$ & $15.81 \mathrm{a}$ & $16.31 \mathrm{~b}$ & $12.69 \mathrm{~b}$ & $12.63 \mathrm{c}$ & $12.66 \mathrm{~b}$ & $75.49 \mathrm{c}$ & $79.89 a$ & $77.69 \mathrm{c}$ & $3.93 b$ & $3.95 \mathrm{a}$ & $3.94 \mathrm{ab}$ \\
\hline \multicolumn{2}{|l|}{ F. test } & $*$ & NS & $*$ & $*$ & $*$ & $*$ & $*$ & $*$ & $*$ & $*$ & $*$ & $*$ \\
\hline \multicolumn{14}{|l|}{ Interaction between $P$ and $N$} \\
\hline \multicolumn{14}{|l|}{ Intercropping patterns } \\
\hline \multirow[t]{2}{*}{$P_{1}(100 \%+50.00 \%)$} & 100 & $17.75 b$ & 17.33 & 17.54 & $13.40 \mathrm{cb}$ & $14.17 \mathrm{a}$ & $13.78 \mathrm{a}$ & $75.49 \mathrm{f}$ & $81.77 \mathrm{~b}$ & $78.63 \mathrm{c}$ & $3.73 b c$ & $4.04 b$ & $3.89 b$ \\
\hline & 120 & $16.00 \mathrm{~d}$ & 15.41 & 15.70 & $12.73 \mathrm{c}$ & $11.90 \mathrm{e}$ & $12.32 \mathrm{e}$ & $79.56 \mathrm{c}$ & $77.22 \mathrm{~h}$ & $78.39 \mathrm{~cd}$ & $3.74 b c$ & $3.58 \mathrm{bc}$ & $3.66 \mathrm{bc}$ \\
\hline Sugar beet : sunflower & 80 & $18.20 \mathrm{~b}$ & 17.30 & 17.75 & $15.18 \mathrm{a}$ & $13.47 \mathrm{c}$ & $14.32 \mathrm{~b}$ & $83.41 b$ & $77.86 f$ & $80.63 b$ & $3.83 b c$ & $3.57 \mathrm{bc}$ & $3.70 \mathrm{bc}$ \\
\hline$P_{2}(100 \%+33.33 \%)$ & 100 & $17.93 b$ & 17.70 & 17.82 & $13.57 \mathrm{~b}$ & $13.92 b$ & $13.74 b$ & $75.68 \mathrm{f}$ & $78.64 \mathrm{e}$ & $77.16 \mathrm{e}$ & $4.00 \mathrm{~b}$ & $4.17 \mathrm{a}$ & $4.09 b$ \\
\hline & 120 & $17.14 \mathrm{c}$ & 15.41 & 16.27 & $12.17 \mathrm{c}$ & $12.66 \mathrm{~d}$ & $12.41 \mathrm{~d}$ & $71.00 \mathrm{~h}$ & $82.15 \mathrm{a}$ & $76.58 \mathrm{f}$ & $3.83 b c$ & $3.91 b$ & $3.87 \mathrm{~b}$ \\
\hline Sugar beet : sunflower & 80 & $17.23 \mathrm{c}$ & 17.07 & 17.15 & $13.31 \mathrm{c}$ & $13.58 b$ & $13.44 \mathrm{c}$ & $77.25 \mathrm{~d}$ & $79.55 d$ & $78.40 \mathrm{~cd}$ & $3.93 b c$ & $3.71 b c$ & $3.82 b$ \\
\hline$P_{3}(100 \%+25.00 \%)$ & 100 & $19.81 \mathrm{a}$ & 17.64 & 18.73 & $17.28 \mathrm{a}$ & $13.51 b$ & $15.40 \mathrm{~b}$ & $87.23 \mathrm{a}$ & $76.59 \mathrm{i}$ & $81.91 \mathrm{a}$ & $5.36 \mathrm{a}$ & $3.94 b$ & $4.65 \mathrm{a}$ \\
\hline & 120 & $17.28 \mathrm{bc}$ & 16.61 & 16.93 & $13.17 \mathrm{c}$ & $13.35 \mathrm{c}$ & $13.26 \mathrm{~d}$ & $76.22 \mathrm{e}$ & $80.37 \mathrm{c}$ & $78.29 \mathrm{~cd}$ & $4.22 b$ & $4.36 \mathrm{a}$ & $4.29 \mathrm{a}$ \\
\hline F. test & & $*$ & NS & NS & $*$ & $*$ & $*$ & $*$ & $*$ & $*$ & $*$ & $*$ & $*$ \\
\hline Solid & & 16.80 & 17.18 & 16.99 & 12.79 & 13.41 & 13.10 & 76.05 & 77.64 & 76.84 & 4.09 & 4.40 & 4.26 \\
\hline
\end{tabular}


Table 3. Plant height $(\mathrm{cm})$,head diameter $(\mathrm{cm})$, seed yield plant $^{-1}(\mathrm{~g}), 100$ seed weight $(\mathrm{g})$ and seed yield fad. ${ }^{-1}(\mathrm{~kg})$ of sunflower as affected by intercropping patterns and $N$ fertilizer levels in both seasons and their combined analysis

\begin{tabular}{|c|c|c|c|c|c|c|c|c|c|c|c|c|c|c|c|}
\hline \multirow{2}{*}{$\begin{array}{l}\text { Main effects and } \\
\text { interaction }\end{array}$} & \multicolumn{3}{|c|}{ Plant height (cm) } & \multicolumn{3}{|c|}{ Head diameter $(\mathrm{cm})$} & \multicolumn{3}{|c|}{ Seed yield plant ${ }^{-1}(g)$} & \multicolumn{3}{|c|}{100 seed weight (g) } & \multicolumn{3}{|c|}{ Seed yield fad. ${ }^{-1}(\mathrm{~kg})$} \\
\hline & 2013/14 & $2014 / 15$ & Comb. & $2013 / 14$ & 2014/15 & Comb. & $2013 / 14$ & $2014 / 15$ & Comb. & $2013 / 14$ & $2014 / 15$ & Cozmb. & $2013 / 14$ & $2014 / 15$ & Comb. \\
\hline \multicolumn{16}{|l|}{ Intercropping pattern (P) } \\
\hline $\begin{array}{l}P_{1}(100 \% \text { sugar beet }+ \\
50.00 \% \text { sunflower })\end{array}$ & $164.56 a$ & $159.00 \mathrm{a}$ & $161.78 \mathrm{a}$ & $10.51 b$ & $11.11 b c$ & $10.81 \mathrm{c}$ & $42.44 \mathrm{bc}$ & $43.33 b$ & $42.89 \mathrm{c}$ & $4.89 b$ & $4.84 c$ & $4.86 \mathrm{c}$ & $600.83 a$ & $590.56 a$ & $595.69 a$ \\
\hline $\begin{array}{l}P_{2}(100 \% \text { sugar beet }+ \\
33.33 \% \text { sunflower })\end{array}$ & $155.78 b$ & $153.22 b$ & $154.50 \mathrm{~b}$ & $14.12 \mathrm{a}$ & $12.27 \mathrm{~b}$ & $13.19 b$ & $44.00 \mathrm{~b}$ & $47.78 \mathrm{a}$ & $45.89 b$ & $6.00 \mathrm{a}$ & $5.54 \mathrm{~b}$ & $5.77 b$ & $360.76 b$ & $473.83 b$ & $417.30 b$ \\
\hline $\begin{array}{l}P_{3}(100 \% \text { sugar beet }+ \\
25.00 \% \text { sunflower })\end{array}$ & $139.78 \mathrm{c}$ & $162.56 a$ & $151.17 \mathrm{~b}$ & $14.26 \mathrm{a}$ & $14.52 \mathrm{a}$ & $14.39 \mathrm{a}$ & $49.89 a$ & $50.33 \mathrm{a}$ & $50.11 \mathrm{a}$ & $6.31 \mathrm{a}$ & $6.43 \mathrm{a}$ & $6.37 \mathrm{a}$ & $230.91 \mathrm{c}$ & $360.31 \mathrm{c}$ & $295.61 \mathrm{c}$ \\
\hline F. test & $*$ & $*$ & $*$ & $*$ & $*$ & $*$ & $*$ & $*$ & $*$ & $*$ & $*$ & $*$ & $*$ & $*$ & $*$ \\
\hline \multicolumn{16}{|c|}{$\mathbf{N}$ fertilizer level $\left(\mathrm{kg} \mathrm{fad}^{-1}\right)(\mathrm{N})$} \\
\hline $\mathbf{N}_{1} 80$ & $150.11 b$ & $152.67 \mathrm{~b}$ & $151.39 \mathrm{c}$ & $11.49 b$ & $11.48 b$ & $11.48 b$ & $43.00 \mathrm{~b}$ & $44.00 \mathrm{c}$ & $43.50 \mathrm{c}$ & $5.01 \mathrm{~b}$ & $5.03 \mathrm{~b}$ & $5.02 \mathrm{~b}$ & $327.26 \mathrm{~b}$ & $452.50 \mathrm{bc}$ & c $389.88 \mathrm{c}$ \\
\hline $\mathbf{N}_{3} 120$ & $158.67 \mathrm{a}$ & $163.11 \mathrm{a}$ & $160.89 a$ & $14.29 a$ & $13.61 \mathrm{a}$ & $13.95 \mathrm{a}$ & $48.22 \mathrm{a}$ & $50.44 \mathrm{a}$ & $49.33 a$ & $6.29 \mathrm{a}$ & $6.02 \mathrm{a}$ & $6.15 \mathrm{a}$ & $444.71 \mathrm{a}$ & $520.44 a$ & $482.58 \mathrm{a}$ \\
\hline F. test & $*$ & $*$ & $*$ & * & $*$ & $*$ & $*$ & $*$ & $*$ & $*$ & $*$ & * & $*$ & $*$ & * \\
\hline Interaction $\mathbf{P} \times \mathbf{N}$ & NS & NS & NS & NS & NS & NS & NS & NS & NS & NS & NS & NS & NS & NS & NS \\
\hline Solid & 155.00 & 162.00 & 158.50 & 15.30 & 15.70 & 15.50 & 50.00 & 51.00 & 50.50 & 6.07 & 6.29 & 6.18 & 1075.00 & 1100.00 & 1087.50 \\
\hline
\end{tabular}

NS and * meaning; Not significant and significant at 0.05 level, respectively. 
sugar beet at 50 and $33.3 \%$ plant density of its pure stand compared with $25 \%$ during combined analysis. These increases may be attributed to the less inter- specific competition under $25 \%$ plant density of sunflower with sugar beet compared with other intercropping patterns. It could be concluded that these traits were decreased by increasing sunflower plant density due to dense sowing lead to a severe competition among sunflower plants for nutrients, water supply and light. Similar results were obtained by Bader and Rashed (1988), Allam and Galal (1996), Al-Thabet (2006) and Osman and Awed (2010).

Results in Table 3 indicate that intercropping sunflower plant density at $50 \%$ with sugar beet $\left(\mathrm{P}_{1}\right)$ occupied the first rank in seed yield fad ${ }^{-1}$ which recorded $595.69 \mathrm{Kg}$, followed by $33.3 \%$ $\left(\mathrm{P}_{2}\right)$ it recorded $417.30 \mathrm{Kg} \mathrm{fad}^{-1}$ while $25 \%\left(\mathrm{P}_{3}\right)$ produced the lowest seed yield $\left(295.61 \mathrm{Kg} \mathrm{fad}^{-1}\right)$. The superiority in seed yield fad ${ }^{-1}$ of sunflower grown in intercropping pattern $\mathrm{P}_{1}$ may be due to increase in number of plants fad ${ }^{-1}$ compared to $\mathrm{P}_{3}$. Similar results were reported by Zhang and Li (2003).

\section{$\mathbf{N}$ fertilizer levels effect}

Results in Table 3 show that sunflower plant height, head diameter, 100 seed weight, seed yield plant $^{-1}$ and seed yield (ton fad. ${ }^{-1}$ ) were significantly increased by increasing nitrogen levels from 80 to 100 and up to $120 \mathrm{Kg} \mathrm{N}$ fad $^{-1}$ by 2.5 and $6.3 \%, 12.9$ and $21.5 \%, 5.9$ and $13.4 \%, 16.3$ and $22.5 \%$ as well as 11.9 and $23.8 \%$ due to $1^{\text {st }}$ and $2^{\text {nd }} \mathrm{N}$ increment for aforementioned traits, respectively in combined analysis. The increase in plant height may be due to $\mathrm{N}$ encourage both meristematic activity and auxin production in plants and thus increase meristematic activity, cell elongation, metabolic processes in plants and in turn increases growth which resulting in the superiority of head diameter, 100 seed weight and seed yield plant ${ }^{-1}$ and consequently increased seed yield fad $^{-1}$ of sunflower plants. These results are in harmony with those obtained by Abd El-Wahed (1996), Al-Thabet (2006) and Ail et al. (2014).

\section{Interaction effect}

plant height, head diameter, 100 -seed weight, seed yield plant ${ }^{-1}$ and seed yield fad ${ }^{-1}$ were not significantly affected by the interaction between intercropping patterns and nitrogen fertilizer levels in both seasons and combined analysis as shown in Table 3.

\section{Competitive Relationships and Monetary Advantage}

\section{Land equivalent ration (LER)}

It is obvious from Table 4 that each $\mathrm{N}$ increment resulted in a significant increase in LER values which calculated on root and seed yields at all intercropping patterns whereas, results conclude that, intercropping pattern $\mathrm{P}_{1}$ $(100 \%$ sugar beet $+50 \%$ sunflower $)$ and fertilized plants with $120 \mathrm{Kg} \mathrm{N}^{-1}$ fad $^{-1}$ recorded the highest LER (1.50) this means that land usage ratios significantly increased by $50 \%$ compared with sugar beet alone. The values of $\mathrm{L}_{\mathrm{B}}$ of sugar beet were higher than those $\mathrm{L}_{\mathrm{S}}$ of sunflower over all intercropping patterns. On the other hand, the lowest value (1.10) of LER was showed with ntercropping pattern $\mathrm{P}_{3}(100 \%$ sugar beet $+25 \%$ sunflower) at $80 \mathrm{Kg} \mathrm{N}^{-1}$. Similar results were obtained by Lal and Mukerji (1998) Tichy et al. (2001) Badraoui et al. (2003) and Abdel Motagally and Metwally (2014).

\section{Land Equivalent Co-efficient (LEC)}

It is obvious from Table 4 that, each $\mathrm{N}$ increment up to $120 \mathrm{~kg} \mathrm{fad}{ }^{-1}$ resulted in a significant increase in LEC values which calculated on root + seed yields at all intercropping patterns whereas, results conclude that, intercropping pattern $\mathrm{P}_{1}(100 \%$ sugar beet $+50 \%$ sunflower) and fertilized sugar beet and sunflower plants with $120 \mathrm{Kg} \mathrm{N}^{-1}$ fad $^{-1}$ recorded the highest LEC value (0.53). On the other hand, the lowest value $(0.20)$ of LEC was showed with intercropping pattern $\mathrm{P}_{3}(100 \%$ sugar beet + $25 \%$ sunflower) at $80 \mathrm{Kg} \mathrm{N} \mathrm{fad}^{-1}$, in this case yield disadvantage. This means that all treatments had LEC values above 0.25 suggesting yield advantages and showed efficient utilization of land resource by growing both crops together and vice versa.

\section{Area time equivalent ratio (ATER)}

The highest area time equivalent ratio (1.15) was obtained with $\mathrm{P}_{1}$ at $120 \mathrm{~kg} \mathrm{~N}$ fad. $^{-1}$ as average of two seasons. This value indicated 
Table 4. Crop yield fad. ${ }^{-1}$, land equivalent ration (LER), land equivalent coefficient (LEC), area time equivalent ratio (ATER), relative crowding coefficient (RCC), aggressivity (Agg.), monetary advantage index (MAI) and gross profit LE fad. ${ }^{-1}$, of sugar beet $\left(\mathrm{L}_{\mathrm{B}}\right)$ and sunflower $\left(L_{s}\right)$ determined on (root + seed) yields basis of both components as affected by the interaction effect between intercropping patterns $x \mathrm{~N}$ fertilizer levels (combined analysis)

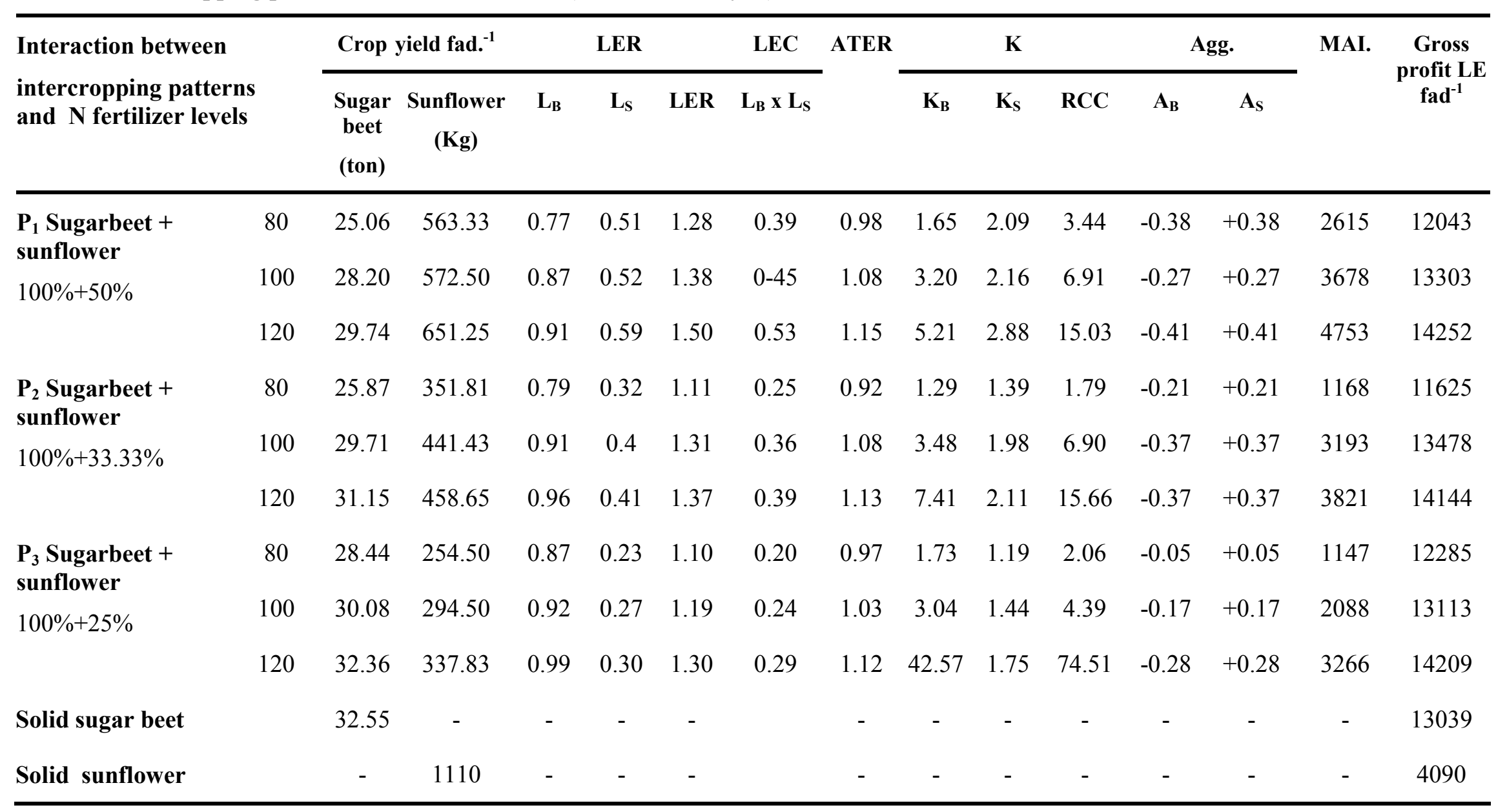


that intercropping pattern was highly efficient in utilizing the growth resources than other pattern of both crops. Whereas, intercropping sunflower with sugar beet at $33.3 \%$ under $80 \mathrm{~kg} \mathrm{~N}$ fad. ${ }^{-1}$ achieved the lowest value 0.92 as an average of the two successive seasons. These results are in harmony with those obtained by Mohammed and Abd El-Zaher (2013).

\section{Relative crowding coefficient (RCC)}

Results in Table 4 indicate that relative crowding coefficient (RCC) were more than one and this means that all treatments achieved yield advantages than solid planting of sugar beet or sunflower. The highest yield advantage for RCC (74.51) was recorded with $(100 \%$ sugar beet + $25 \%$ sunflower) at $120 \mathrm{Kg} \mathrm{N}$ fad. $^{-1}$ and the lowest value of RCC (1.79) was showed by using $(100 \%$ sugar beet $+33.33 \%$ sunflower $)$ under $80 \mathrm{Kg} \mathrm{N} / \mathrm{fad}^{-1}$.

\section{Aggressivity (Agg)}

Results presented in Table 4 indicates the effect of intercropping patterns and $\mathrm{N}$ fertilization on aggressivity values (A) of sugar beet $\left(A_{B}\right)$ and sunflower $\left(A_{S}\right)$ calculated for roots + seeds yields. It is known that an aggressivity value of zero indicates that, both component crops are equally competitive. For any other situation, both crops will have the same numerical value by positive for the dominant crop and negative for the dominated one. The greater the numerical value, the larger the differences in competitive abilities. Results in Table 4 indicate that the component crops did not compete equally. Regardless intercropping pattern was a positive sign for sunflower and negative for sugar beet thereby that the sunflower was dominant while sugar beet was dominated of all intercropping patterns. This means that sunflower more aggressivity than sugar beet under different $\mathrm{N}$ fertilizer levels in this study. Aggressivity recorded the best value with minimum aggressivity $(0.05)$ in $\mathrm{P}_{3}$ at $80 \mathrm{~kg}$ $\mathrm{N}$ level. While the maximum values $(0.41)$ were achieved with $\mathrm{P}_{1}$ at $120 \mathrm{~kg} \mathrm{~N}$ level.

However, the negative sign for sugar beet and the positive one for sunflower may be due to the ability of the shorter component to compete with the taller component for available nutrients, especially $\mathrm{N}$ in this respect. This further, emphasizes that sunflower is able to acquired more resources than that sugar beet in the sugar beet-sunflower relay intercropping. These results are in line with the conclusion of Long et al. (2001), Ghosh et al. (2006) and Egbe (2010). However, Ghosh et al. (2004) further explained that because of the differences in canopy texture in height of sunflower and sugar beet, the two species not only competed for nutrient and water but also for sunlight. Our results indicate that, land use of the sugar beet/sunflower intercropping pattern was more efficient than sole cropping, which may be due to a more rational use of environmental resources in intercropping situations. Also Koji et al. (2016) suggest that intercropping is more useful cultivation system than double cropping to increase the annual soybean production.

\section{Monetary advantage index (MAI)}

Concerning monetary advantage index, results in Table 4 reveal that index of monetary advantage were positive in all treatments. $100 \%$ sugar beet $+50 \%$ sunflower under $120 \mathrm{Kg} \mathrm{N}$ $\mathrm{fad}^{-1}$ gave the highest value $(4753 \mathrm{LE})$ for monetary advantage index, while $100 \%$ sugar beet $+25 \%$ sunflower with adding $80 \mathrm{Kg} \mathrm{N}$ fad. ${ }^{-1}$ gave the lowest value $(1147 \mathrm{LE})$ for this characters similar trends were obtained by Stoyanov et al. (1997) and Tichy et al. (2001).

\section{Gross profit}

Results presented in Table 4 indicate that the maximum gross profit $14252 \mathrm{LE}$ achieved with $\mathrm{P}_{1}(50 \%+100 \%)$ at $120 \mathrm{~kg} \mathrm{~N}$ fertilizer level and was at par with gross profit (14209 LE) produced by $\mathrm{P}_{3}(25 \%+100 \%)$ at the same level of $\mathrm{N}$ fertilizer. However, the lowest value 11625 LE was recorded when sugar beet intercropped with sunflower at $33.3 \%$ under $80 \mathrm{~kg} \mathrm{~N}$ level in combined analysis these results are in harmony with those obtained by Mohammed and Abd El-Zaher (2013).

\section{Conclusion}

It could be concluded that from this study intercropping sunflower at $25 \%$ plant density of its pure stand with $100 \%$ sugar beet achieve the highest root yield fad. ${ }^{-1}$ (32.36 ton $+337.83 \mathrm{~kg}$ seed of sunflower) and gross profit $14209 \mathrm{LE}$ at $(120 \mathrm{Kg} \mathrm{N}$ fad) while the maximum sugar yield fad. $^{-1}$ (4.21 ton), sucrose (\%) and purity (\%) for sugar beet achieved at (100 Kg $\mathrm{N}$ fad.) in average of two seasons. The best land usage and monetary advantage index were recorded when intercropped sunflower at $50 \%+100 \%$ sugar beet with $120 \mathrm{Kg} \mathrm{N}$ fad. 


\section{REFERENCES}

AOAC (1990). Official Methods of Analysis of the Association of Official Agricultural Chemists, $15^{\text {th }} \mathrm{Ed}$. Washington, DC, USA.

Abd El-Wahed, A.E. (1996). Response of sunflower to phosphorus and potassium fertilization under different levels of nitrogen. Proc. $7^{\text {th }}$ Conf. Agron., (1): 429-437.

Abdel Motagally, F.M.F. and A.K. Metwally (2014). Maximizing productivity by intercropping onion on sugar beet. Asian $\mathrm{J}$ Crop Sci., 6 (3): 226-235.

Aditiloye, P.O., F.O.C. Ezedinma and B.N. Okigbo (1983): A land equivalent coefficient concept for the evaluation of competitive and productive interactions on simple complex mixture. Ecol. Modeling, 19 : 27 - 39.

Ahmed, S.E., A.M. Abou-Salama, G.R. ElNaggar and F.M.F.A. Motagally (2009). Studies on legume-black cumin intercropping. Egypt. J. Appl. Sci., 24:553563.

Ali, A., A. Ahmed, T. Khaliq, M. Afzal, Z. Igbal and R. Qamar (2014). Plant population and nitrogen effects on achene yield and quality of sunflower (Helianthus annuus L.) hybrids. Int. Conf. on Agric., Environ. and Biol. Sci., (AEBS-2014) April 24 - 25, Phuket (Thailand).

Allam, A.Y. and A.H. Galal (1996). Effect of nitrogen fertilization and plant density on yield and quality of sunflower. Assiut J. Agric. Sci., 27 (2): 1617.

Al-Thabet, S.S. (2006). Effect of plant spacing and nitrogen levels on growth and yield of sunflower (Helianthus annus L.). King Saud Univ. Riyadh. J. Agric. Sci., 19: 1-11.

Badawi, M.A. (1989). A preliminary study on the effect of some cultural practices on the growth and yield of sugar beet. J. Agric. Sci. Mansoura Univ., 14 (2): 984-993.

Bader, A.M. and A.H. Rashed (1988). Effect of some plants spacing and nitrogen fertilizer levels on growth and yield of sunflower.1.yield and yield components. Iraqi J. Agric. Sci., Zanco, 6 (4):163-175.
Badraoui, M., M. Agbani, R. Bouabid, M. ElGharous, M. Karrou and M. Zeraouli (2003). New recommendations for the wheat-sugar beet and sunflower cropping in the Doukkala and Gharb irrigated regions of Morocco. Proc. Regional Workshop of the Int. Potash Inst., Amman, 113-119.

Carruthers, A. and J.F.T. OldField (1961). Methods for the assessment of sugar beet quality. Int. Sug., 63 (1):103-105.

De-Wit, C.T. (1960). Intercropping its important and research needs. Part 1 . Competition and yield advantages. Verslag Langbov WKundige onderzoek No. 66: 1 - 82. [CA. Willey, RW, 1979 (CF Field Crop Abst., 32, $1-10)$.

Egbe, O.M. (2010). Effect of plant density of intercropped soybean with tall sorghum on competitive ability of soybean and economic yield at Otobi, Benue State, Nigeria. J. Cereals and Oilseeds, 1 (1):1 - 10 .

El-Dessougi, H., A. Dreele and N. Claassen (2003). Growth and phosphorus uptake of maize cultivated alone, in mixed culture with other crops or after incorporation of their residues. J. P1. Nut. Soil Sci., 166 (2): 254261.

El-Hannawy, H.H., B.S.H. Ramadan and E.A. Mahmoud (1998). Response of sugar beet to nitrogen fertilization levels and its time of application. J. Agric. Sci., Mansoura Univ., 23 (3): 969-978.

El-Kassaby, A.T, and A.A. Leilah (1992). Influence of plant density and nitrogen fertilizer levels on sugar beet productivity. Proc. $5^{\text {th }}$ Conf. Agron. Zagazig Univ., 13-15 (2): 954-962

Fahmi, Mahasen M. (1999). Effect of levels and times of nitrogen application on growth and yield of sugar beet. Ph. D. Thesis, Fac. Agric., Mansoura Univ.

Ghosh, P.K., M.C. Manna, K.K. Bandyopadhyay, A.K. Tripathi, P.H. Wanari, K.M. Hati, A.K. Misra and C.L. Acharya (2006). Interspecific interaction and nutrient use in soybean/ sorghum intercropping system. Agron. J., 98: 1097 - 1108 .

Ghosh, P.K., P. Ramesh, K.K. Bandyopadhyay, A.K. Tripathi, K.M. Hati, A.K. Misra and 
C.L. Acharya (2004). Comparative effectiveness of cattle manure, poultry manure, phosphocompost and fertilizer-NPK on three cropping systems in vertisols of semi-arid tropics. 1. Crop yields and system performance. Bioresource Technol., 95: $77-83$.

Hattendorf, M.J., M.S. Redefs, B. Amos, L.R. Stone and R.E. Gwin (1988).Comparative water use characteristics of six row crops. Agron. J., (80) : 80-85.

Hiebsch, C.K. and R.E. McCollum (1987). Area time equivalency ratio: a method of evaluating the productivity of intercrops. Agron. J., 79: 15-22.

Koji Y., A. Ikoma and M. Iijima (2016). Performance of double cropping and relay intercropping for black soybean production in small-scale farms. Plant Prod. Sci., 19 (4): 449-457.

Lal, M. and N. Mukerji (1998). Productivity of intercropping system in sugarcane with sugar beet and wheat. Madras Agric J., 80 (4) : 177-179.

Le-Docte, A. (1927). Commercial determination of sugar in the beet root using the sacks LeDocte Process. Int. Sug. J. (29): 488 - 492 [C.F. Sugar beet Nutrition, 1972. Appl. Sci. Publishers L. td (London A.P. Draycott)].

Long, L., S. Jianhao, Z. Fusuo, L. Xiaolin, Y. Sicum and R. Zdenko (2001). Wheat/maize or wheat/soybean strip intercropping. 1-Yield advantage and interspecific interactions on nutrients. Field Crops Res., 71:123-137.

Mohammed, W.Kh. and Sh.R. Abd El-Zaher (2013). Effects of intercropping sunflower with sugar beet under different plant densities and defoliation levels on yield and production efficiency of both crops. Ann, Agric. Sci., Moshtohor, 51 (4) : 351- 538

Monzon, J.P., J.L. Mercau, J.F. Andrade, O.P. Caviglia, A.G. Cerrudo, A.G. Cirilo, P. A. Calvino (2014). Maize-soybean intensification alternatives for the Pampas. Field Crops Res., 162:48-59.

Neana, S.M. (1999). Effect of nitrogen fertilizer and some growth regulators on the yield and quality of sugar beet. Ph.D. Thesis Fac. Agric., Alex. Univ., Egypt.
Osman, E.B.A. and M.M.M. Awed (2010). Response of sunflower (Helianthus annuus L.) to phosphorus and nitrogen fertilization under different plant spacing at new valley. Ass. Univ. Bull. Environ. Res., 13 (1):11-19.

Salama, A.M. and M.A. Badawi (1996). Evaluation of six sugar beet cultivars under $\mathrm{N}-$ levels and harvesting dates. J. Agric. Sci. Mansoura Univ., 21 (1): 139- 153

Shalaby, A.M. (1995).Sunflower yield and nutrients uptake as influenced by plant type and interaction between phosphorus and other nutrients. Minufiya. J. Agric. Res., 20 (3): 1277-1295.

Sorour, S.R., S.H. Abou-Khadrah, M. Zahran and E.A. Neamet-Alla (1992). Effect of different potassium and nitrogen rates on growth and yield of sugar beet cultivars. Proc. $5^{\text {th }}$ Con.Agro., Zagazig, 13-15 Sept., (2): 1027-1043.

Steel, R.G.D., J.H. Torrie and D.A. Dicky (1997). Principles and Procedures of Statistics, a biological Approach. $3^{\text {rd }}$ Ed. MacGraw Hill Book Co. New Yourk, 172 - 177.

Stoyanov, D., I. Atanassove and S. Stratieva (1997). Increase of sugar beet and sunflower yields. Pochvoznanie, Agrokhimiya y Ekologiya, 3 (3) :16-20.

Tavakoli, P.A. (2013). Effect of plant density on yield and yield components of sunflower varieties in temperate regions of Kermanshah. Euro. J. Exp. Bio., 3 (5): 601-604.

Tichy, I., Z. Muchova and H. Franakova (2001).Technological quality of wheat barley and sugar beet in relation to nutrition. Ahrochemia, 28 (12):362-365.

Umrani, N.K., S.H. Shinde, and P.M. Dhonde (1984). Studies on intercropping of pulses in kharif sorghum. Ind. J. Agron., 29 (1): 27-31.

Willey, R.W. (1979). Intercropping its importance and research needs. Part 1: Competition and yield advantage. Field Crop Res., 32: 1-10.

Zhang, F.S. and L. Li (2003).Using competitive and facilitative interactions in intercropping systems enhances crop productivity and nutrient-use efficiency. Plant -Soil, 248:305312. 
تأثير نظم التحميل ومستويات السماد النيتروجيني على إنتاجية بنجر السكر و دوار الثمس المحملين

\author{
أحمد محمد شيحه ـ أميرة عطية الميهي - ياسر احمد عبدالحليم حفنى

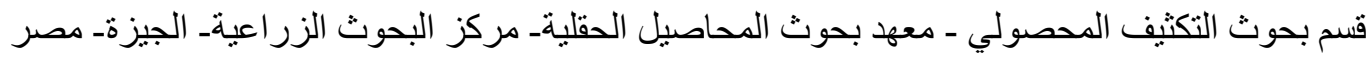

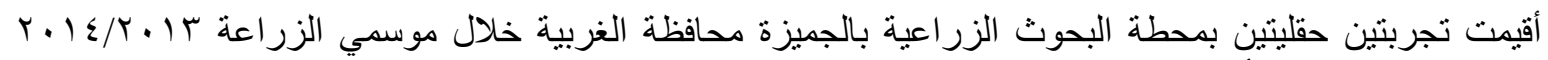

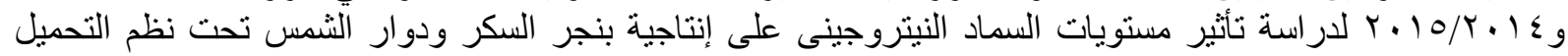

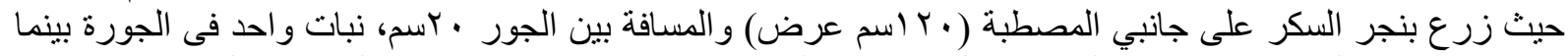

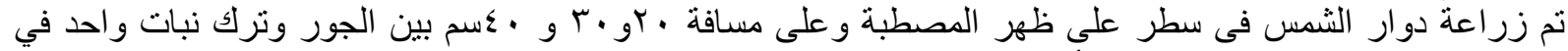

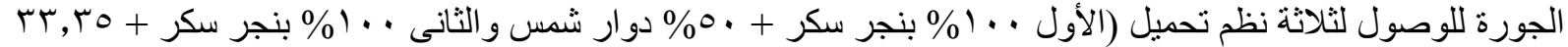

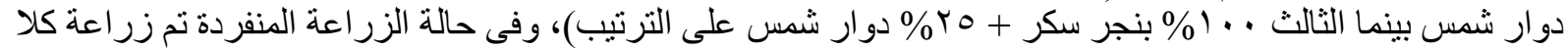

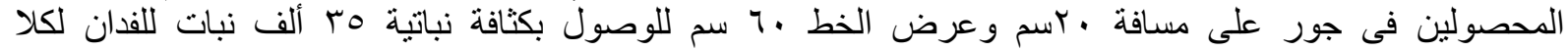

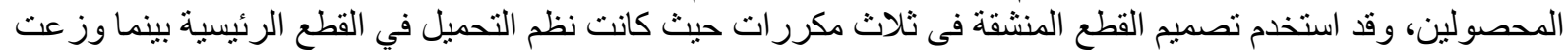

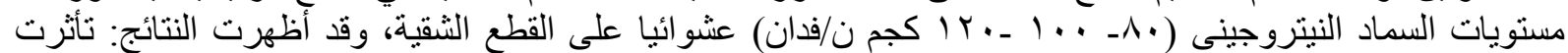

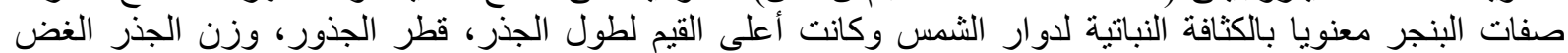

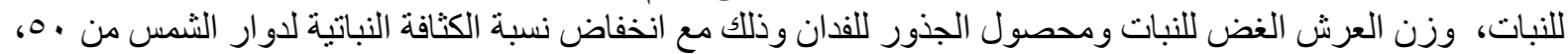

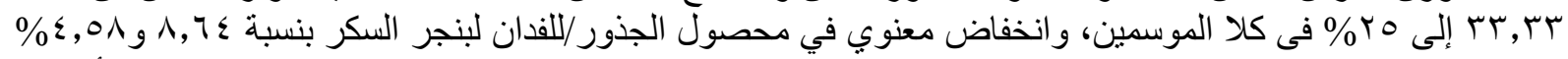

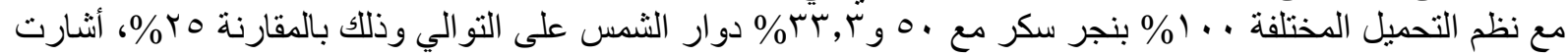

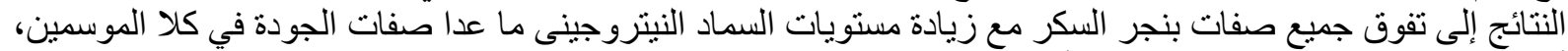

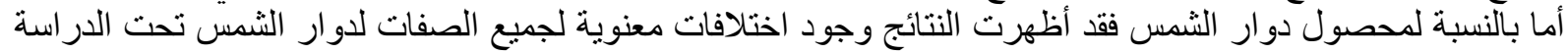

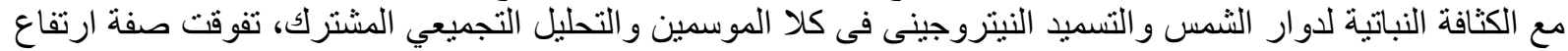

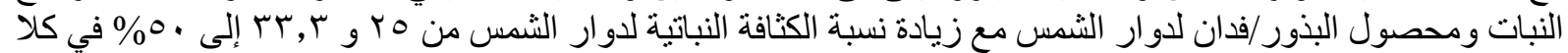

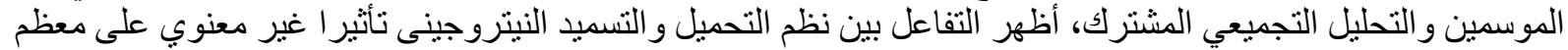

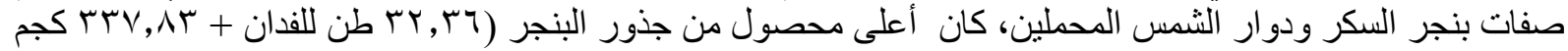

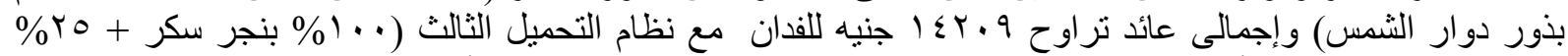

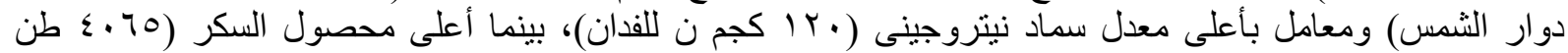

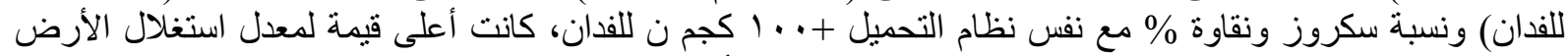

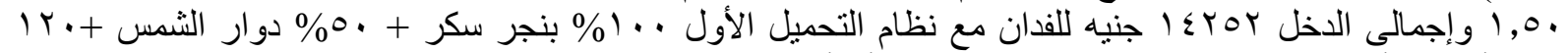

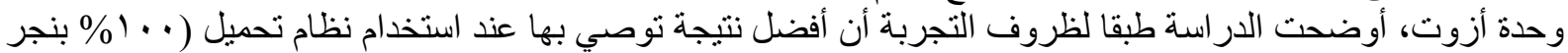

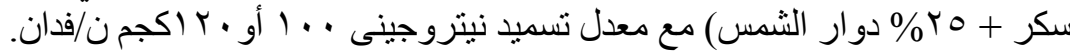

